\title{
FRAQUEZA DA VONTADE NO VOLUNTARISMO? INVESTIGAÇÕES SOBRE JOÃO DUNS SCOTUS
}

Jörn Müller*

SÍNTESE - Neste estudo, investiga-se a possibilidade de uma análise, por parte de Duns Scotus, do clássico problema de filosofia moral localizado na fraqueza da vontade. Argumentando de modo crítico para a identificação do tema na ética scotista, o autor acaba por expor, com isso, as premissas centrais de toda a metafísica da vontade e a ética da liberdade de Duns Scotus.

PALAVRAS-CHAVE - Fraqueza da vontade. Vontade. Liberdade. Voluntarismo. Teoria da ação scotista.
ABSTRACT - In this study the hypothesis of finding in Duns Scotus's works a real analysis of the classical problem of moral philosophy located in the weakness of the will is deeply investigated. Arguing critically for the identification of that theme in the ethics of Scotus, the author outlines at the same time the central premises for Duns Scotus's metaphysics of the will and ethics of freedom.

KEY WORDS - Weakness of will. Will. Freedom. Voluntarism. Scotus's theory of action.

Numa descrição adequada tanto ao linguajar do dia-a-dia quanto ao filosófico, "fraqueza da vontade" designa o fundamental "fenômeno de que alguém não faz aquilo que toma como o melhor para si, muito embora pudesse fazê-lo". ${ }^{1}$ Não é de admirar que tal fato aparentemente evidente (e, em vários aspectos, desagradável) da experiência pessoal prática deu vazão a uma grande quantidade de tentativas de interpretação filosófica, começando com a negação socrática do fenômeno, no diálogo Protágoras (351b-358e), de Platão, chegando até ao passado recente. ${ }^{2}$ Sem dúvida, a contribuição medieval para o problema foi, até aqui, apreciada apenas em abordagens rudimentares. Isso se deve à seguinte acepção de muitos pesqui-

\footnotetext{
Bonn - Alemanha

Cf. U. WOLF, Zum Problem der Willensschwäche, in: Zeitschrift für philosophische Forschung, 39 (1985), p. 21-33.

Estudo exemplar é o famoso ensaio de D. DAVIDSON, How is weakness of the will possible?, in: D DAVIDSON, Essays on actions and events, Oxford, 1980, p. 21-42 (originalmente in: J. FEINBERG (ed.), Moral concepts, Oxford, 1969, p. 93-113). Um bom panorama acerca do desenvolvimento histórico do conceito foi oferecido, recentemente, por A. HÜGLI, Willensschwäche, in: Historisches Wörterbuch der Philosophie, 12 (2004), p. 800-809.
}

\begin{tabular}{|l|l|l|l|l|l|}
\hline VERITAS & Porto Alegre & v. 50 & n. 3 & Setembro 2005 & p. 117-138 \\
\hline
\end{tabular}


sadores, raramente feita de maneira explícita: o paradigma "intelectualista" da ética e da teoria da ação antigas foi substituído, com a introdução de um conceito autônomo de vontade, no cristianismo, por um paradigma "voluntarista". Por meio disso, porém, o problema da fraqueza da vontade perde aparentemente o seu específico filosófico: na medida em que a vontade decide de forma autônoma acerca das ações humanas, uma ação contra o próprio conhecimento racional não é mais problema algum. ${ }^{3}$

$\mathrm{Na}$ pesquisa mais recente, indicou-se de modo convincente, contrariamente, pois, a essa acepção generalizada, que autores medievais tiveram claramente o mérito, ao menos na forma de comentário ao entendimento aristotélico da fraqueza da vontade, no Livro VII da Ética a Nicômaco, de mostrar compreensão do fenômeno. ${ }^{4}$ Como mostra Tomás de Aquino, a título de exemplo, produziram-se também aqui, através do comentário puro sobre a akrasia aristotélica (em latim incontinentia), contribuições altamente originais para a descrição e a explicação do fenômeno. ${ }^{5}$ Sem dúvida, poder-se-ia talvez renovar a tese acima colocada acerca da aparente perda de significado da fraqueza da vontade na Idade Média, na medida em que se volta a autores que, claramente, não se localizam na tradição aristotélica como Tomás de Aquino se localizava. Autores desta última tradição são também freqüentemente caracterizados como "intelectualistas", na medida em que apontam para uma relação próxima entre pensamento e vontade. No entanto, não deveria ser renovada a tese, no que diz respeito aos seus adversários no debate medieval sobre a liberdade humana, no final do século 13 e no início do século 14, isto é, aos assim chamados "voluntaristas", uma vez que em tais autores "voluntaristas" a autonomia da vontade, diante da razão e dos seus juízos, é especialmente acentuada?

João Duns Scotus parece ser, pois, uma das principais testemunhas de que, para um voluntarista, o problema da fraqueza da vontade perde a sua agudeza filosófica. Ao menos se deixou interpretar assim o diagnóstico respectivo ao aparecimento dos equivalentes terminológicos do fenômeno: o termo latino escolhido para a tradução da akrasia aristotélica, isto é, incontinentia, e as formas cognatas (incontinens, incontinenter, etc.) se encontram muito raramente na sua obra, assim como as expressões que se referem ao mesmo assunto, como, por exemplo, peccare ex passione. ${ }^{6}$ Scotus não escreveu um comentário à Ética a Nicômaco, e as

Cf., sobre isso, W. CHARLTON, Weakness of will. A philosophical introduction, Oxford, 1988, p. 5-7.

Cf., sobre isso, o trabalho inovador de R. SAARINEN, Weakness of the will in Medieval thought. From Augustine to Buridan, Leiden/New York/Köln, 1994, p. 87-193.

5 Os textos centrais para a abordagem de Tomás de Aquino, nas suas obras teológicas, são STh I-II q. 77, a. 1-2; II-II q. 156, a. 1-4; De malo q. 3, a. 9-11. Acerca da contribuição tomasiana para o debate sobre a fraqueza da vontade, cf. J. MÜLLER, Willensschwäche als Problem der mittelalterlichen Philosophie. Überlegungen zu Thomas von Aquin, in: Recherches de Théologie et Philosophie Médiévales, 72 (2005), p. 31-58.

6 Sobre esta ausência terminológica considerável, cf. T. HOFFMANN, L'“Akrasia” selon Duns Scot, in: O. BOULNOIS et al. (Hrsg.), Duns Scot à Paris 1302-2002. Actes du colloque de Paris, 2-4 septembre 2002, Turnhout, 2004, p. 487-516 (p. 489), bem como T. NOONE, Scotus on Incontinentia, p. 1s. Trata-se, neste último caso, de um estudo apresentado no encontro "Akrasia und incontinentia. 
suas remissões à Etica a Nicômaco VII, nas suas obras teológicas - nas quais eu entrarei, depois, com um pouco mais de detalhes -, quase se podem contar nos dedos de uma mão. Significa isso que a fraqueza da vontade não desempenha papel algum no pensamento de Duns Scotus?

Para responder a esta pergunta, primeiro devem ser valorizadas as passagens - daí os conceitos - na obra de Scotus que são imediatamente relevantes, de início, para um entendimento aristotélico-tomasiano tradicional da fraqueza da vontade (1). Em seguida, analisa-se a crítica de Scotus à interpretação de Henrique de Gand acerca da akrasia aristotélica, a partir da qual ficará claro qual tipo de ação contra o melhor juízo realmente interessa a Duns Scotus, a saber, o peccatum ex malitia, por conseguinte a fraqueza da vontade refletida (2). A possibilidade, por conseguinte a explicabilidade de tais ações, na acepção scotista, será apresentada na seção (3). Disso resultará, em que medida há justificação em falar de um desaparecimento da fraqueza da vontade como problema filosoficamente significativo em Scotus (4).

\section{Scotus e o peccare ex infirmitate}

Scotus apresenta, em seguimento a Pedro Lombardo, ${ }^{7}$ uma classificação de tipos de pecado, a qual se mostra grandemente relevante para a sua discussão da fraqueza da vontade. Ele diferencia por intermédio das três Pessoas divinas, daí dos predicados respectivos a elas, os seguintes tipos de pecado: ${ }^{8}$

(a) Um pecado contra o Pai (peccatum in Patrem) se explica pela fraqueza da vontade, na medida em que ela está inclinada, através da sua ligação com o desejo sensível, a seguir desejos sensíveis. Com isso, é negado o predicado de "poder" (potentia). ${ }^{9}$

(b) No caso do pecado contra o Filho (peccatum in Filium), mostra-se desconhecimento, isto é, o predicado divino negado é a "sabedoria" (sapientia), e a ação sucede a partir de desconhecimento.

\footnotetext{
Das Problem der Willensschwäche in der Philosophie des Mittelalters" (Jena, 12.-14. August 2004), ainda não publicado. Eu o cito, na seqüência, de acordo com o número das páginas da versão apresentada na ocasião.

Cf. PETRUS LOMBARDUS, Sent. II d. 43, c. un., n. 11, SB IV 577

8 Cf., quanto ao que segue, Secundae additiones secundi libri, d. 43 q. 1, ed. C. Bali (Les commentaires de J. Duns Scot sur les quatre livres de Sentences, Louvain, 1927), p. 313, e Opus Oxoniense II d. 43, q. 2, ed. A. B. Wolter (Duns Scotus on the will and morality, Washington, 1986), p. 478. Cf. também as análises de W. HOERES, Der Wille als reine Vollkommenheit nach Duns Scotus, München, 1962, p. 117s. Na seqüência, serão citados os textos de Scotus de acordo com a edição parisiense das obras, 1891-1895 (=ed. Viv.), com a Opera omnia editada desde 1950, pela Comissão Scotística do Vaticano (=ed. Vat.), com a seleção de textos já mencionada de Wolter (=W), ou ainda de acordo com outras edições existentes.

9 Cf. Opus Oxoniense II d. 43, q. 2, W p. 478: "Voluntas enim, quia coniuncta est appetitu sensitivo, nata est condelectari sibi, et ita peccans efficaciter ex inclinatione appetitus sensitivi ad suum delectabile, peccat ex infirmitate sive impotentia". Secundae additiones d. 43, q. 1, p. 314: "Patri appropriatur potentia, ideo peccatum ex infirmitate vel passione dicitur esse contra Patrem".
} 
(c) Ao lado destes dois tipos, há um terceiro, que não se deve nem à influência das paixões sensíveis nem ao erro, mas procede unicamente da vontade. Neste caso, Scotus fala do pecado contra o Espírito Santo (peccatum in Spiritum Sanctum) e da negação do seu predicado, isto é, a "bondade" (bonitas). ${ }^{10}$

Os três tipos de pecados não são diferenciados, portanto, primariamente segundo determinados conteúdos ou objetos, ${ }^{11}$ mas sim de acordo com os fatores causalmente determinantes, a cada vez, de maneira que se obtém a seguinte classificação: (a) peccatum ex infirmitate/impotentia/passione; (b) peccatum ex ignorantia; (c) peccatum ex malitia.

Os tipos (a) e (b) são, por sua vez, particularmente interessantes para o contexto de discussão aristotélico-tomasiana acerca da fraqueza da vontade, na medida em que se trata, nesta tradição, de um equívoco do juízo prático, resultante da influência das paixões e, daí, resultante da fraqueza da vontade. Assim, como se pode reconstruir o pecar por fraqueza, no entendimento scotista?

É claro que, aqui, não se pode voltar a um querer que se deve, em sentido causal próprio, à influência das paixões: como Henrique de Gand, Scotus representa a concepção de que as passiones não podem operar imediatamente sobre a razão, por conseguinte sobre o juízo prático, mas apenas pela mediação da vontade. Apenas a vontade está numa relação imediata com o appetitus sensitivus. ${ }^{12}$ A própria vontade, porém, fundamentalmente não pode ser obrigada ao "consentimento" (consensus) às paixões, uma vez que, do contrário, não se poderia falar de uma liberdade da vontade. ${ }^{13}$ Scotus concede que o surgimento dos desejos não reside no âmbito de disposição da vontade, porém certamente a tomada de posição afirmativa e/ou negativa desta em relação àqueles. Na base desse conceito pronunciado de vontade, daí de liberdade da vontade, Scotus oferece nitidamente algumas reflexões de como se pode imaginar uma ação contra o melhor juízo que se diferencia do peccare ex malitia.

No centro das atenções está, aqui, a relação da vontade com o conhecimento racional. Scotus partilha, sim, da opinião de que sempre pertence a um querer humano próprio, no sentido pleno da expressão, uma forma de conhecimento: apenas o que é conhecido pode ser querido. Disso não se segue, contudo, que esse conhecimento relevante à ação deva sempre se dar como conhecimento claro e pleno. Antes, Scotus parte da concepção de que a consciência humana, ao lado

${ }^{10}$ Cf. Opus Oxoniense II d. 43, q. 2, W p. 478: "Tertium enim esset peccatum ipsius [voluntatis] secundum se ex libertate sua, non ex condelectando appetitui sensitivo, neque ex errore rationis et illud esset ex malitia, et appropriate contra Spiritum Sanctum, cui attribuitur bonitas".

11 O pecado contra o Espírito Santo seguramente ainda é precisado, em termos de conteúdo, em Secundae additiones d. 43, q. 1, p. 314, na verdade em termos de infrações contra os mandamentos da primeira tábua do Decálogo.

12 Cf., sobre isso, Ord. III suppl. d. 33, W p. 332.

13 Cf. a resposta inequívoca de Scotus à pergunta se pode haver um consentimento sob coação (consensus coactus), em Ord. IV d. 29, W p. 174: "Dico quod coactio non cadit proprie in homine in aliquo actu humano. Contradictio enim est voluntatem simpliciter cogi ad actum volendi. [...] Sed ad actionem voluntatis elicitam vel imperatam, quae sola est proprie actio humana, non potest cogi nisi secundum quid, metu scilicet maioris mali quam sit ille actus". 
de representações claras e perfeitas, por conseguinte de conhecimentos, pode conter também conhecimentos e representações indistintas e imperfeitas (indistinctae et imperfectae intellectiones). ${ }^{14}$ A vontade, agora, na sua atividade, não está de modo algum fixada a conteúdos sedimentados num modo epistemicamente superior, mas pode dirigir o seu querer também a algo que, por assim dizer, ocorre no modo semi- ou subconsciente. ${ }^{15}$ Ao mesmo tempo, ela pode subtrair, aqui, a atenção de conteúdos cognitivos existentes já em forma clara e plena, portanto no modo consciente, e enfraquecê-los correspondentemente. ${ }^{16} \mathrm{Com}$ isso, apresenta-se um modelo de fraqueza da vontade, cuja característica essencial reside na condução direcionada da atenção intelectual por meio da vontade: no agir sob vontade fraca, a atenção de um conhecimento racional claro existente é desviada a um conhecimento até então subconsciente, o qual, contudo, se depara antes com a vontade, no seu direcionamento ao desejo sensível. O conteúdo cognitivo original é, portanto, volitivamente impelido, daí reprimido, para um plano secundário. ${ }^{17}$ A pressuposição central deste modelo está na capacidade da vontade de poder governar diretivamente a razão na sua atividade cognitiva. Com a acentuação de momentos subconscientes e do controle de atenção dependente da vontade causalmente, e de modo imediato, Scotus aponta para uma descrição de uma ação sob vontade fraca, a qual, sem dúvida, ainda poderia ser explorada, por exemplo, com respeito ao conflito subcutâneo de motivos de ação racionais e irracionais ou ao momento de auto-engano, que está implicado na descrição dos processos psíquicos no decorrer dessa ação. Algo acerca desses assuntos se encontra ainda na crítica de Scotus ao modelo de fraqueza da vontade de Henrique de Gand (cf. seção 2).

Sem dúvida, Scotus deixa isso predominantemente no âmbito da descrição e da análise do agir sob vontade fraca no sentido aristotélico-tomasiano, assim como em observações e também com respeito à disposição a partir da qual esse modelo de ação é explicável, por conseguinte possível. Aqui, dever-se-ia remeter, por um lado, para a deficiência geral, daí para a inferioridade da vontade criatural face ao correspondente divino: o peccare ex infirmitate dificilmente é pensável, sem uma fraqueza fundamental da potência humana da vontade, e o próprio Scotus tem isso absolutamente em vista: assim, a fixação da vontade criatural no bem

Cf., sobre isso e quanto ao que segue, Opus Oxoniense II d. 42, q. 1-4, n. 10-11, W p. 172. 174.

15 Cf. ibid., W p. 174. 176: "illis ergo confusis et imperfectis [scil. intellectionibus] ibi existentibus potest voluntas [...] complacere in qualibet earum, etiamsi illa intellectio non fuerit cognita ut obiectum actualiter". Cf. também Additiones magnae d. 25, q. 1, ed. C. Bali , p. 281: "voluntas, cum sit libera, et tota causa actus volendi secundum dictam opinionem potest tanto conatu agere in obiectum obscure cognitum, sicut in obiectum clare cognitum, quia cum habeat totam causalitatem in se et libere potest agere pro volito intensius et remissius".

16 Cf. Opus Oxoniense II d. 42, q. 1-4, n. 10-11, W p. 172: "[...] voluntate complacente intellectioni intellectio firmatur et intenditur, ipsa autem non complacente infirmatur et remittitur".

${ }_{17}$ Cf. ibid., W p. 174: "voluntate complacente in aliqua intellectione confirmat illam et intendit. Illa igitur, quae fuit remissa et imperfecta, fit per istam complacentiam perfecta et intensa, et sic potest imperare cogitationem et convertere intellectum ad illam. Voluntate autem nolente aliam intellectionem, et non complacente in ea, illa remittitur vel desinit esse, et sic dicitur voluntas avertere intellectum ab intellectione illius". 
não é, em sua intensidade, comparável àquela da voluntas divina. ${ }^{18}$ Mais específica para a fraqueza da vontade como fenômeno sui generis aparece, contudo, nesse sentido, uma análise intencionada primariamente em sentido lógico, a qual Scotus invoca com respeito à utilização de incontinens em Aristóteles, no seu comentário ao escrito Sophistici elenchi. Scotus constata que Aristóteles utiliza a expressão, ao final, de modo equívoco, dado que ela ora caracteriza um ser humano que ultrapassa, em termos gerais, as fronteiras da recta ratio, e ora alguém que faz isso com respeito a um determinado âmbito de objetos, algo como nos prazeres que se baseiam no gosto, por conseguinte no tato. ${ }^{19}$ Incontinentia descreve, com isso, ou uma disposição moral geral do agente ou uma disposição objetivamente específica. Scotus, por sua vez, tende claramente a ver a incontinentia como um nível geral de maturidade moral, daí como uma constituição habitual deficiente, a partir da qual ações errôneas contra a recta ratio podem, em geral, ser explicadas. ${ }^{20}$ Obscuro permanece, em Scotus, onde se teria precisamente de localizar essa disposição: na medida em que os hábitos de virtude e de vício, entendidos como forças secundárias na produção da ação, são localizados por Scotus na própria vontade (e a esta também devem ser atribuídas, na forma de tristitia e gaudium, passiones próprias), ${ }^{21}$ ficaria forçoso tomar também isso como incontinentia. Ação sob vontade fraca, na forma descrita, seria devida, então, a uma disposição geral (de menor valor) na própria potência da vontade. ${ }^{22}$

Com efeito, Scotus claramente não está interessado num aprofundamento da discussão da fraqueza da vontade como peccare ex infirmitate e na sua explicação. A relação de vontade, paixões e juízo racional na fraqueza da vontade aristotélico-tomasiana, que recebe uma longa discussão em Henrique de Gand, ${ }^{23}$ é es-

${ }^{18}$ Cf. Lect. I d. 48, q. un., n. 2, ed. Viv. X p. 780a: "Non enim voluntati creatae congruit ita intense velle aliquod obiectum bonum, sicut voluntati increatae, et intensio actus respectu obiecti in agente creato et increato, est differens multum in eis". Sobre a comparação da vontade criatural e divina e sobre a fraqueza específica da vontade humana, em Scotus, cf. HOERES, Der Wille als reine Vollkommenheit [nota 8], p. 113-115.

19 QO. sup. Elench. q. 16, ed. Viv. II p. 25a: "Ad tertium dico quod, incontinens' significat excessum rationis in gustabilibus et tangibilibus, et significat excessum rationis simpliciter, et hoc aequivoce. [...] ideo , incontinens', quod significat excessum rationis in communi, potest determinari ad alterum eorum, ita quod possit accipi pro excessu rationis in ira, vel in lucro, sic dicendo, incontinens irae, vel lucri'".

${ }^{20}$ Ao menos ele interpreta a continentia, em Aristóteles, de acordo com esse sentido, o que sugere uma correspondência "a modo de imagem inversa" para com a incontinentia. Cf. Ord. III suppl. d. 33, W p. 376: "Ad illud Philosophi de virtute heroica, quod adducitur pro opinione prima, dico quod in omni bonitate assignat quatuor gradus, qui sunt eiusdem habitus in specie, scilicet perseverantiam, continentiam, temperantiam, et heroica".

${ }^{21}$ Cf. Ord. III suppl. d. 33, W p. 328, bem como B. KENT, Virtues of the will. The transformation of ethics in the late Thirteenth Century, Washington, 1995, em especial p. 238-245.

22 Cf. NOONE, Scotus on Incontinentia [nota 6], p. 11: "We should expect to see [...] incontinentia treated as a habitual moral condition, primarily located in the will though perhaps secondarily in the sense appetite [...]".

23 Cf. HEINRICH VON GENT, Quodlibet I q. 17, ed. R. Macken (Leuven - Leiden 1979), p. 115-150. No centro desta Quaestio está a incontinentia, tal como o próprio Henrique de Gand atesta: "de hoc est principaliter difficultas quaestionis, scilicet de peccato incontinentis, qui peccat ex passione, de quo est dubitatio, utrum passio sensualis prius inficiat voluntatem pravo consensu et mediante illa 
boçada por ele, ao final, apenas en passant. Sem dúvida, a partir da crítica que Scotus elabora contra a concepção de Henrique de Gand, pode-se obter alguma coisa sobre o seu próprio entendimento da fraqueza da vontade, como também sobre a pergunta de qual vem a ser, para ele, com respeito ao fenômeno "agir contra o melhor juízo", o ponto saliente.

\section{A crítica de Scotus a Henrique de Gand e à sua interpretação da fraqueza de vontade}

Essencialmente, formam-se dois âmbitos relevantes para a discussão da fraqueza da vontade, nos quais Scotus critica Henrique de Gand: (A) a pergunta pela ligação necessária da "prudência" (prudentia) com as virtudes morais, no contexto de discussão da connexio virtutum $;^{24}$ (B) a localização da consciência na vontade ou na razão.

(A) Scotus dá um rumo próprio à afirmação de Henrique de Gand de que as virtudes particulares estão ligadas necessariamente à prudência, ${ }^{25}$ em que ele, para tanto, introduz dois argumentos, extraídos de escritos aristotélicos. O primeiro é tirado imediatamente da discussão aristotélica sobre a akrasia: "E isso é provado pelo Filósofo, no terceiro capítulo do Livro VII da Ética a Nicômaco, onde a sua opinião é esta: se a vontade elege mal, o intelecto ordena mal". ${ }^{26} \mathrm{O}$ segundo argumento invoca a concepção apresentada por Aristóteles, em De motu animalium, de que a conclusão do silogismo prático é idêntica à ação. Isso, contudo, não deixaria mais nenhum lugar para um ato da vontade que se distingue do juízo da razão: antes, a vontade seria determinada pelo juízo da razão. ${ }^{27}$ Isso significaria, contudo, relacionado à temática da connexio virtutum, que, a partir de um juízo de razão correto, da parte da prudência, seriam geradas, forçosamente, ações virtuosas e, com isso, seriam gerados também hábitos virtuosos: quem estivesse de posse da prudentia teria necessariamente de dispor, por conseguinte, também das virtudes morais. Do contrário, um juízo de razão falso necessariamente precederia, como deve mostrar o primeiro argumento, uma má decisão da vontade (electio).

obnubilet rationem ut in iudicio suo erret, vel e converso passio illa rationem primo obnubilet ut erret, et tunc necessario cogatur sequi deordinatio voluntatis appetentis secundum iudicium rationis errantis" (ibid., p. 119). Sobretudo a discussão dos argumentos por Henrique de Gand (ibid., p. 130150) pode ser lida, por vezes, como um comentário ao Livro VII da Ética a Nicômaco. Importante também é o Quodlibet X de Henrique de Gand, ed. R. Macken (Leuven - Leiden 1981), sobretudo as questões 10 e 13, às quais Scotus se volta de modo imediato e crítico; cf. abaixo, seção 2.

Cf. Ord. III suppl. d. 36, W p. 392-410.

25 Cf. HEINRICH VON GENT, Quodlibet V q. 17, ed. Badius 1520, f. 189D-190F

${ }^{26}$ Ord. III suppl. d. 36, W p. 392: „Quod probatur per Philosophum VII Ethicorum, capitulo tertio, ubi sententia sua est si voluntas male eligit, intellectus male dictat".

${ }^{27}$ Cf. ibid., W p. 394: „Item, De motu animalium, si maior proponatur ab intellectu practico [Wolter: practica], et minor assumatur [sub add. Wolter] a sensu vel phantasia, conclusio erit operatio; ita quod necesse est operari secundum eam si non impediatur. Numquam igitur secundum eum est operatio omnino contraria dictamini rationis". 
Em suma, esses dois argumentos incorporam duas teses, que foram condenadas em 1277, em Paris. Uma reza que da retidão da razão segue-se a retidão da vontade; a outra que, após ter sido concluído um silogismo prático, a vontade não tem mais nenhuma possibilidade de agir contra o juízo de razão correspondente. ${ }^{28}$ Exatamente no sentido da condenação dessas duas teses, Scotus defende a liberdade da vontade contra o perigo de um determinismo intelectual, através do que ele cria, ao mesmo tempo, espaço para um agir genuíno contra o melhor juízo. Ele não deixa nenhuma dúvida de que a vontade pode voltar-se fundamentalmente, na sua decisão, contra o juízo de razão, portanto não se dá nenhuma necessitação da vontade. De fato, supõe-se para a vontade que ela se liga ao juízo de razão, mas sempre lhe é possível percorrer caminhos próprios, e exatamente nisso ela se diferencia do intelecto teórico, que assente necessariamente às suas conclusões. ${ }^{29}$ Mas, isso também significa que um hábito da prudência pode ser produzido através de atos de juízo corretos, sem que, por conseqüência, seja produzido necessariamente, por meio de decisões da vontade correspondentes, um hábito virtuoso na vontade. ${ }^{30}$ Finalmente, isso leva a que se retire da prudentia uma qualidade imediatamente prática, que dirige a ação, e que se a desloque ao estatuto de uma potência de juízos puramente teórico-conciliatórios, ${ }^{31}$ com o que a tese de Henrique de Gand da ligação necessária da prudência com as virtudes morais não pode mais ser mantida.

Própria parece ser, pois, a crítica a Scotus de que o seu combate ao determinismo intelectual se encontra, em termos de conteúdo, completamente na linha dos esforços de Henrique de Gand: também este acentua, afinal, a liberdade absoluta da vontade na sua decisão face a todos os juízos da razão prática, e a sua análise da akrasia aristotélica leva, ao final, à conclusão de que ela, enfim, é um "desordenamento da vontade" (deordinatio voluntatis), e não o erro da razão, a que se deixam reduzir, em sentido causal, as ações sob vontade fraca, também no modelo aristotélico-tomasiano. ${ }^{32}$ De fato, exatamente nas suas tomadas de posição

28 Cf. R. HISSETTE, Enquête sur les 219 articles condamnés à Paris le 7 Mars 1277, Louvain/Paris, 1977, n. 166 ("Ouod si ratio recta, et voluntas recta") e n. 169 ("Ouod voluntas, manente passione et scientia particulari in actu, non potest agere contra eam"). Como indica a nota à paixão (manente passione), trata-se, aqui, de um artigo que está ligado imediatamente ao peccare ex passione, daí à fraqueza da vontade. Scotus o reformula, contudo, de tal forma que semelhante relação não mais é visível: "stante scientia in universali e particulari de aliquo, voluntas non potest velle oppositum" (Ord. III suppl. d. 36, W p. 394).

29 Cf. Rep. II A d. 39, q. 1-4, n. 5, ed. Viv. XXIII p. 205a: "intellectus practicus est, qui necessario assentit agibilibus, voluntas autem libere. Quidquid igitur est onus impositum voluntati, dico quod non est aliquid receptum in voluntate ab intellectu ostendente. Sed potest dici naturalis ordo, quia difficile est voluntatem non inclinari ad id quod est dictatum a ratione practica ultimatim, non tamen est impossibile".

${ }^{30}$ Cf. Ord. III suppl. d. 36, W p. 400: "simpliciter rectum dictamen potest stare in intellectu absque recta electione illus dictati in voluntate, et ita cum unicus actus rectus dictandi generet prudentiam, generabitur ibi prudentia absque omni habitu virtutis moralis in voluntate".

${ }_{31}$ Cf. também Ord. I d. 17, q. 1-2, n. 91, ed. Vat. V p. 184.

32 Cf. HEINRICH VON GENT, Quodlibet I q. 17, p. 129: "Dicendum igitur est absolute [...] quod omnis deordinatio per errorem in ratione causaliter procedit ex deordinatione voluntatis per pravam affectionem, et non e converso [...]". 
acerca da fraqueza da vontade se encontra, por assim dizer, o subtexto para a crítica de Scotus, pois Henrique de Gand, aqui, chegara ao resultado de que, ao final, tem também sempre lugar um desordenamento do juízo prático: da maldade da vontade segue-se, por meio de um processo gradual de "obnubilação" (obscuratio, obnubilatio) da razão, finalmente, um completo "cegamento" (excaecatio), que se estende até ao âmbito dos princípios práticos (portanto, da premissa maior do silogismo prático): em última instância, a fraqueza da vontade aceita temporariamente uma premissa maior falsa, em outras circunstâncias abandonada pela vontade, e deduz, a partir disso, um juízo prático enganoso, o qual, então, é recebido a modo de condução de ação na vontade ${ }^{33}$. Essa forma de leitura da fraqueza da vontade tinha permitido a Henrique de Gand buscar uma quadratura do círculo, na medida em que conseguiu harmonizar a condenação de 1277 e, parecendo diametralmente oposta, em termos de conteúdo, a propositio magistralis de Egídio Romano, concedida oficialmente em Paris, em 1285/6 ("numquam est malitia in voluntate, nisi sit error vel saltem aliqua nescientia in ratione"): ${ }^{34}$ o erro da razão e o desordenamento da vontade aparecem no modelo de Henrique de Gand como simultâneos, em sentido temporal; causalmente, porém, devem ser reduzidos apenas e unicamente à vontade. ${ }^{35}$

Scotus abandona essa tentativa de harmonização, realizada por Henrique de Gand, e, com isso, também rejeita absolutamente a sua explicação da fraqueza da vontade. Para tanto, podem aduzir-se dois motivos: (i) ele aceita uma separação mais aguda da esfera teórica e da prática, por conseguinte da razão e da vontade. Isso se expressa, sobretudo, na sua crítica à idéia de Henrique de Gand acerca de um "cegamento" da razão ("excaecatio"), até os princípios mais elevados, sucedido na fraqueza da vontade. De acordo com a sua concepção, a vontade, em última instância, não está em condições de desviar realmente os prima principia autoevidentes a todos os seres humanos para um seu oposto fático, e tampouco pode ela tornar inócuos os tipos de raciocínio silogístico fundamentais. ${ }^{36}$ A vontade

33 Cf. HEINRICH VON GENT, Quodlibet X q. 10, p. 262: "paulatim primo obscuratur ratio per primam malitiam aliquantulum, et crescit obscuratio plus et plus secundum quod crescit et augmentatur malitia voluntatis. [...] obscurata ipsa ratione in sua notitia et deficiente claritate eius, incipit iudicium vacillare et deficere a sua firmitate et rectitudine. [...] Ut demum augmentata obscuratione, ad augmentationem malitiae tantum dubitatio est de illis principiis, et tandem ratione excaecata, deficit omnino rectitudo iudicii circa principium et notitia intellectualis terminorum, et per appetitum sensualem ex notitia sensuali quam habet de terminis, iudicat oppositum principii, ut quod furtum est bonum".

34 AEGIDIUS ROMANUS, Apologia a. 51, ed. R. Wielockx, Opera Omnia III.1, Florenz, 1985, p. 59. Cf. também ibid., a. 24, p. 54, bem como: In I Sent. d. 17, p. 1, princ. 1, q. 1, ed. Venedig 1521 (ND Frankfurt a.M., 1968), f.89M; d. 47, princ. 2, q. 1, f.237G. Cf. E. HOCEDEZ, La condamnation de Gilles de Rome, in: Recherches de Théologie Ancienne et Médiévale 4 (1932), p. 34-58.

35 Cf. HEINRICH VON GENT, Quodlibet I q. 17, p. 147: "Ouod autem ex parte voluntatis qua debet homo esse practicus, prius deordinetur incontinens (prius, dico non duratione sed causalitate: simul enim fuit error rationis et deordinatio voluntatis), quam ex parte rationis qua debet homo esse sciens, aperte patet [...]". Cf., nesse sentido, também Quodlibet X q. 9, p. 245s.

${ }_{36}$ Cf. Ord. III suppl. d. 36, W p. 398: "mala electio non potest excaecare intellectum, ita quod erret circa agibilia [...] igitur impossibile est voluntatem facere intellectum considerantem principia per deductionem syllogisticam, erraret circa conclusionem et multo magis nec circa ipsa principia, et 
pode, de fato, subtrair-se de todo juízo prático, mas ela não pode, por mera preferência, modificá-lo segundo o conteúdo ou a estrutura. Se, pois, o discurso da excaecatio da razão deve fazer, aqui, algum sentido, então, segundo Scotus, devese seguir somente um dos dois seguintes modos de leitura: (a) interpretação privativa: a vontade desvia a razão do juízo correto, na medida em que ela dirige as reflexões para motivos pseudo-racionais a favor do oposto conhecido como correto ou para objetos irrelevantes. Não se trata, então, de desordenamento algum, mas sim de um mero desvio da razão. (b) Interpretação positiva: a vontade põe à razão simplesmente um fim de ação particular falso e dirige a atenção primariamente à deliberação dos meios que conduzem à realização desse fim. Também aqui não há nenhum desordenamento da atividade da razão, mas sim uma instrumentalização unilateral, a qual impele a recta ratio para o segundo plano. ${ }^{37}$

Scotus concede, também, em certa medida, que uma forma de ignorância cognitiva (ignorantia), induzida pela vontade, está envolvida, mas abandona a tese de que um "erro" (error) da razão tem lugar necessariamente. Essas interpretações se coadunam muito bem com os desdobramentos na seção 1, em que se mostrou a possibilidade, em Scotus, de uma fraqueza da vontade no sentido aristotélico-tomasiano, conjugada com o motivo do comando da atenção intelectual pela vontade.

(ii) Ademais, Scotus, em oposição a Henrique de Gand, não tem primariamente a intenção de encontrar um modelo que ofereça uma explicação plausível da akrasia, daí do peccare ex infirmitate/passione no horizonte voluntarista. Interessalhe, em primeira linha, a possibilidade do peccatum ex certa malitia, o qual justamente não se deixa explicar com a teoria de Henrique de Gand: como é possível que alguém passe sobbre o seu próprio juízo de razão sem um prévio equivocamento através das paixões, por conseguinte sem o envolvimento de algum déficit cognitivo, fazendo, ainda, aquilo que é por ele mesmo totalmente conhecido como ruim? A dificuldade de tal fraqueza da vontade refletida está primeiramente no âmbito de teoria da ação, e mais precisamente, também por parte da autoridade, no bem provado princípio sub ratione boni: se se aceita que tudo o que é querido

ideo nullo modo excaecabitur intellectus ita ut erret". Cf. também Ord. II d. 7, q. un., n. 88, ed. Vat. VIII p. 116: "sicut prima speculabilia sunt vera ex terminis, sic et prima principia operabilia, - et per consequens, intellectus qui potest concipere quiditatem terminorum primi principii practici et illos componere, habet sufficiens motivum et, per modum naturae' movens ad assentiendum illi principio; igitur per voluntatem, cuius actus est posterior, non potest impediri, - vel saltem non fertur in contrarium". Cf. também Rep. II d. 7, q. 1-3, n. 28, ed. Viv. XXII p. 637a ("non potest esse intellectus ita excaecatus, quod erret circa prima principia practica").

${ }^{37}$ Cf. Ord. III suppl. d. 36, W p. 400. 402: "Dici potest quod [scil. intellectus] excaecatur dupliciter: uno modo privative; alio modo positive; privative, quia [malitia] avertit [intellectum] a recta consideratione; voluntas enim eligens oppositum alterius rectae dictati non permittit intellectum diu stare in illo recto dictamine, sed avertit ipsum ad considerationes pro opposito, si quae possunt esse rationes sophisticae vel probabiles ad illud; aut saltem avertit ad considerandum aliquid aliud impertinens, ne stet illa actualiter displicentia quae stat in remorsu illo qui habetur in eligendo oppositum dictati. Positive autem excaecat sic: nam sicut voluntas recte eligens finem praecipit intellectui considerare illa, quae sunt necessaria ad illum finem, et intellectum sic inquirendo media ordinata ad illum findem rectum generat in se habitum prudentiae, ita voluntas eligens sibi malum finem potest quidem sibi praestituere malum finem, sicut dictum est distinctione prima primi, imperat intellectum considerare media necesaria ad consequendum illum finem". 
é querido apenas como bom, então o procedimento falho e a pecaminosidade têm sempre de estar enraizados em alguma forma de ignorância ou de erro ${ }^{38}$ Exatamente em relação à pergunta pela possibilidade de uma fraqueza da vontade refletida é que Henrique de Gand não havia se pronunciado de modo realmente conclusivo, o que, em última análise, está fundamentado no caráter de compromisso acarretado pelo seu modelo. Scotus, que não mostra disposição alguma de levar em consideração a propositio magistralis, advoga explicitamente, em contraposição a isso, a possibilidade do peccatum ex certa malitia, por conseguinte uma fraqueza da vontade refletida, e radicaliza, assim, a abordagem voluntarista. ${ }^{39} \mathrm{Na}$ seção 3, voltar-me-ei às implicações respectivas à teoria da ação presentes nessa radicalização, sobretudo no que diz respeito ao princípio sub ratione boni.

(B) A crítica de Scotus ao conceito de consciência de Henrique de Gand se concentra na localização daquele na vontade, bem como na relação do juízo de consciência com a ação volitiva ${ }^{40}$ Henrique de Gand vê a consciência como sediada na vontade, como uma estrutura de juízo paralela à racionalidade prática. ${ }^{41} 0$ juízo de ação da razão prática vem à tona, na medida em que os princípios universais da lei natural são aplicados à situação de ação isolada. Em termos de analogia de estrutura, há, da parte da vontade, uma consciência geral (synderesis), que se detém no seguimento dos princípios da lei natural, e uma instância dirigida à situação particular respectiva, a saber, o ato de consciência (conscientia). Na medida em que synderesis e conscientia são caracterizadas como instâncias de motivação (a saber, como motor universalis, daí como motor particularis) da ação, Henrique de Gand caracteriza a sua localização na esfera prático-afetiva da vontade. ${ }^{42}$ Para que um juízo (teórico) da razão prática se torne um juízo de consciência, ele necessita, com isso, de acordo com Henrique de Gand, da sua capturação ativa na vontade. Por isso mesmo, um saber teórico de ação não deve per se ser igualado a um saber moral condutor da ação, isto é, nem todo aquele que tem conhecimento

${ }^{38}$ Aqui, o próprio Scotus apresenta as comprovações relevantes: "Ad hoc etiam est illud dictum Dionysii 4 De divinis nominibus: , Nullus operatur aliquid ad malum aspiciens' et illud de III Ethicorum, c. 3: , Omnis malus ignorans', cui concordat illud Sapientiae: , Excaecatur eos malitia eorum'" (Ord. III suppl. d. 36, W p. 394).

39 Isso é o que mostram as discussões sobre a temática do peccatum ex certa malitia, daí do peccatum in Spiritum Sanctum: Ord. II d. 43, q. un., ed. Vat. VIII p. 485-487; Lect. II d. 43, q. un., n. 4-6, ed. Vat. XIX p. 402s.; Rep. II d. 43 q. un., n. 4, ed. Viv. XXIII p. 229a: "potest esse peccatum in Spiritum Sanctum precise [...]. Dico tamen breviter, quod omne peccatum, quod est in voluntate non precedente perturbatione ex passione nec precedente ignorantia in ratione, est peccatum ex certa malitia, et sic forte peccavit Adam, quia in eo non fuit perturbatio ex passione precedente nec ignorantia".

${ }^{40}$ Cf. Rep. II d. 39 q. 1-2, ed. Viv. XXIII p. 203-208; Lect. II d. 39 q. 1-2, ed. Vat. XIX p. 377-387; Ord. II d. 39, W p. 196-204.

41 Cf., para o que segue, HEINRICH VON GENT, Quodlibet I q. 18, p. 150-155.

42 Cf. ibid., p. 152: "quia conscientia ad partem animae cognitivam non pertinet, sed ad effectivam [ms.: affectivam]. Sicut enim in cognitiva sunt lex naturalis ut universalis regula operandorum et ratio recta ut particularis, sic ex parte voluntatis est quidam universalis motor stimulans ad opus secundum regulas universales legis naturae, et dicitur, synderesis', quae est in voluntate quaedam naturalis electio semper concordans cum naturali dictamine legis [...] et quidam motor particularis stimulans ad opus secundum dictamen rationis rectae, et dicitur , conscientia', quae est in voluntate quaedam electio deliberativa semper concordans cum dictamine rectae rationis". 
do que é devido está motivado da mesma maneira a segui-lo no seu juízo de consciência, por conseguinte nas suas ações. ${ }^{43}$ A realização de uma reivindicação de consciência (conscientia) correspondente pode, portanto, ficar de fora. Esses desdobramentos, a propósito, adaptam-se muito bem à análise da akrasia por parte de Henrique de Gand: não faltam qualidades cognitivas ao que sofre de fraqueza da vontade, mas sim qualidades afetivas, razão por que ele não transpõe o seu conhecimento racional para a condução da ação.

Scotus certamente visualiza nesse modelo o perigo de que, em última análise, sejam colocadas cadeias na vontade, na produção dos seus atos, e isso, na verdade, em dois sentidos: (a) através do juízo da razão prática é afixada à vontade um tipo de peso, do qual se poderia subtrair, num juízo de consciência, apenas com muita dificuldade. ${ }^{44}$ Com isso, porém, surge de novo a ameaça de um tipo de determinismo intelectual, que Scotus combate de modo tão decidido. ${ }^{45}$ (b) Quando o juízo de consciência está ancorado na vontade mesma e possui força motivacional, como é possível ainda um pecado contra a consciência (peccatum contra conscientiam) $)^{46}$ ? Sem dúvida, por experiência própria, não é algo real que nós sempre seguimos a nossa consciência. Com isso, teria também de ser colocado, entre o juízo de consciência e a execução da ação, um ato posterior, que a vontade pode realizar livremente, o que, porém, levaria tão-só à reduplicação redundante do conteúdo do ato de eleição volitivo, bem como à pergunta de como a vontade pode estar em conflito consigo mesma, nesse âmbito.

Para ambos os problemas, há, sem dúvida, pontos de referência em Henrique de Gand: assim, ele restringe significativamente a possibilidade de um agir contra o juízo próprio a juízos da razão prática (a qual, não obstante, impõe à vontade uma espécie de tendência de direção), enquanto juízos de consciência completos não são condenáveis sem maiores explanações ${ }^{47}$. Contra isso, pois, Scotus mantém

${ }^{43}$ Cf. ibid.: "Et semper formatur conscientia a consensu et electione liberae voluntatis iuxta iudicium et sententia rationis [...] ex hoc contingit quod aliqui multam notitiam operandorum habentes, nullam vel modicam habent in se conscientiam de operando secundum scientiam".

44 Cf. Lect. II d. 39, q. 1-2, n. 11, ed. Vat. XIX p. 380: "sed dicunt quod 'conscientia' est habitus sicut motor particularis, secundum quem habitum voluntas prona est ad concorditer eliciendum secundum dictamen syllogismi practici; quod ideo est pondus quoddam, secundum eos, impressum voluntati ab intellectu practico". Cf. Rep. II d. 39, q. 1-2, n. 3, ed. Viv. XXIII p. 204a: "Circa conclusionem correspondet in voluntate motor particularis, et dicitur esse conscientia, ita quod per electionem est assensus illi, quod est conclusum syllogismo practico. [...] Similiter et alibi dicit idem Doctor [scil. Henricus] quod illud dictamen rationis imponit onus voluntati, etsi est dictatum ratione demonstrativa imponit onus necessario voluntati, ita quod non est in potestate voluntatis recipere vel non recipere".

${ }_{45}$ Cf. Lect. II d. 39, q. 1-2, n. 22, ed. Vat. XIX p. 383: "sed, secundum istos, illud pondus in voluntate, quod dicitur 'conscientia', causatur ab intellectu practico per syllogismum practicum; igitur actus intellectus practici continet virtualiter actum voluntatis - quod falsum est, quia, secundum istos, voluntas est potentia nobilior, et ita actus eius erit nobilior".

${ }^{46}$ Cf. Lect. II d. 39, q. 1-2, n. 20, ed. Vat. XIX p. 382s.: "Contra id quod dicunt de conscientia arguitur primo sic: aliquis potest agere contra conscientiam suam [...] sed contra habitum in voluntate non potest agere proprie, quia iste habitus, conscientia' (si ponitur in voluntate) naturaliter inclinat ad assentiendum huic dictato".

${ }^{47}$ Cf. HEINRICH VON GENT, Quodlibet IX q. 5, ed. R. Macken (Leuven, 1983), p. 136. 
inequivocamente: "Também quando o juízo de consciência é completo, a vontade pode querer o contrário daquilo que é ordenado de acordo com ele [isto é, com o juízo de consciência]" ${ }^{48}$. Como isso é possivel?

Scotus desfaz o nó górdio do juízo de consciência e do ato concreto da vontade primeiramente pelo fato de que ele localiza tanto a synderesis quanto a conscientia, não mais na vontade, mas sim na razão (intellectus) ${ }^{49}$. Desse modo, ele obtém um espaço de explicação não-desconsiderável para o agir contra a própria consciência e oferece, nisso, algumas interpretações que ficam absolutamente em consonância com uma interpretação aristotélico-tomasiana do agir sob fraqueza da vontade. Com remissão imediata ao Livro VII da Ética a Nicômaco, ele explica como algo possível que o saber relevante resida, não num estado atual, mas sim num estado habitual, portanto não esteja imediatamente diante do olho espiritual do agente ${ }^{50}$. Igualmente, fala-se aqui da possibilidade de que o saber é dado de fato na forma de um juízo de consciência no estado atual, porém a vontade o enquadra, através da condução direcionada da atenção intelectual, e com isso, por assim dizer, o neutraliza - isso está em correspondência com os desdobramentos a nós já conhecidos acerca da fraqueza da vontade num sentido mais atenuado. ${ }^{51} \mathrm{~A}$ objeção de que, no caso de uma localização da consciência no intelecto, aquele que possui um saber prático maior dispõe também, ao mesmo tempo, de uma consciência mais fortemente desenvolvida (o que não é evidente per se) é recusada por Scotus com remissão ao Livro VII da Ética a Nicômaco: há que se diferenciar entre um saber prático realmente internalizado e uma mera reprodução verbal do mesmo, isto é, pode ser o caso que alguém saiba falar muito bem sobre a reta práxis, sem que disponha, porém, de uma consciência formada correspondentemente. O verdadeiro saber moral, ao contrário, conduz também sempre a uma correspondente formação da consciência. ${ }^{52}$

Decisivo, pois, é o seguinte: com esse deslocamento à razão, fez-se do juízo de consciência, pensado, em Henrique de Gand, como motivador da ação, um juízo em última análise teórico-especulativo, com relação ao qual a vontade pode se comportar livremente. Exatamente isso é expresso na citação acima, a saber,

48 "Stante conscientia perfecta, voluntas potest velle oppositum eius quod dictatur secundum illam" (Ord. II d. 39, q. 1-2, n. 18, ed. Vat. VIII p. 461s.).

49 Cf. Lect. II d. 39, q. 1-2, n. 24-25, ed. Vat. XIX p. 384; Rep. II d. 39, q. 1-2, n. 4. 7, ed. Viv. XXIII p. 204b. 206a; Ord. II d. 39, W p. 200. 202.

${ }^{50}$ Cf. Rep. II d. 39, q. 1-2, n. 7, ed. Viv. XXIII p. 206a: "Ideo dico quod conscientia est in intellectu, et si est actualis, est dictamen actuale in intellectu, et si est habitualis, est dictamen habituale, et ideo est concors scientiae rectae. Unde vult Aristoteles 7 Ethicorum quod sicentia practica est dictamen conforme se habens appetitui recto, et tamen habens maiorem scientiam habitualem, non propter hoc patet maiorem scientiam actualem, quia actu non considerat; illa enim scientia habitualis quasi dormit".

51 Cf. ibid.

${ }^{52}$ Lect. II d. 39, q. 1-2, n. 31, ed. Vat. XIX p. 386: "dico quod Philosophus dicit libro Ethicorum quod , quidam dicunt verba Empedoclis, sciunt autem nequaquam'; ita sunt aliqui qui bene dicunt verba de operabilibus et legunt Bibliam, sed tamen non habent conscientiam. Unde dico quod illi qui sunt magis et vere scioli de operabilibus, magis sunt conscientiosi; aliter si conscientiam non habent, habent tantum verba". O mesmo pensamento, igualmente com remissão à passagem de Ética a NiCômaco 1147a19-22, se encontra também em Ord. II d. 39, W p. 204. 
que também é possível se desviar de um juízo de consciência perfeito (conscientia perfecta). Com essa recolocação da consciência, que está em contradição com o restante da tradição franciscana, ${ }^{53}$ Scotus criou definitivamente espaço para um agir também relacionado com juízos de consciência contra o melhor juízo e, com isso, também para uma fraqueza de vontade refletida, no pleno sentido da palavra: somente quando se dá um peccatum contra conscientiam não-sujeito a limitações no âmbito do possível é que se pode falar de um peccatum ex certa malitia. De fato, Scotus, com isso, criou para si dois novos problemas: por um lado, a diferença entre juízos de razão e de consciência foi tendenciosamente nivelada, de forma que os juízos morais não são mais uma expressão real da personalidade. Por outro lado, emerge de novo a pergunta como se pode, em absoluto, no âmbito da teoria da ação, justificar tal agir contra a própria consciência: como é possível não querer o bem conhecido claramente no âmbito do ditame da consciência?

\section{Como é possível uma fraqueza da vontade refletida? Scotus e o peccatum ex certa malitia}

A crítica a Henrique de Gand exigiu explicitar um claro ponto de convergência: Scotus radicaliza a possibilidade da ação contra o juízo próprio, por conseguinte contra juízos, nos termos de um peccatum ex certa malitia. Numa passagem central, ele explica:

À vontade é possível atribuir um pecado a partir de maldade decidida, quando a vontade, a partir da sua liberdade - sem uma paixão no apetite sensitivo e um equívoco de razão - peca: ali, pois, está a mais explícita forma de pecado, porque nada diferente da vontade a alicia para o mal [...]: porque ela, a partir da liberdade pura, sem nenhuma ocasião extrínseca, elege para si querer o mal. ${ }^{54}$

De qualquer modo, Scotus, na mesma passagem, e em outras, acentua que a vontade, apesar dessa descrição, não pode querer o mal diretamente sub ratione mali ${ }^{55}$. Dessa posição, contudo, não resulta em Scotus, de modo algum, uma aceitação ilimitada do princípio sub ratione boni, como mostram as seguintes reflexões:

53 Cf., por exemplo, PETRUS IOANNIS OLIVI, In II Sent. qq. 81-82, ed. B. Jansen, BFS VI p. 175: "Quia autem huiusmodi approbationes vel reprobationes seu sententiales contestificationes fiunt communiter cum quodam affectuali stimulo aut de praeteritis actis vel neglectis remordente aut ad agenda stimulante: hinc est quod conscientia sumpta sive pro actu sive pro habitu sive pro potentia, ut subest illis, includit in se communiter intellectum et voluntatem et aliquos utriusque actus vel habitus seu habituales inclinationes et dispositiones".

${ }^{54}$ Cf. Ord. II d. 43, q. un., n. 6, ed. Vat. VIII p. 486s.: "potest [voluntati] assignari peccatum ex certa malitia, quando voluntas ex libertate sua - absque passione in appetitu sensitivo et errore in ratione - peccat: ibi enim est plenissima ratio peccati, quia nihil aliud a voluntate alliciens eam ad malum [...] quia ex plena libertate - sine aliqua occasione extrinseca - eligit sibi malum velle".

55 Cf. ibid.: "non ponatur voluntas creata posse velle malum sub ratione mali [...] non tamen ex malitia ita quod voluntas peccans tendat in malum in quantum malum". Cf. também Ord. III suppl. d. 36, W p. 392s.: "Item, suppono duo: [...] secundo, quod voluntas nihil possit velle sub ratione mali". In Lect. II d. 43, q. un., ed. Vat. XIX p. 402, encontra-se, por sua vez, a afirmação: "Igitur videtur quod voluntas potest ferri in malum immediate". Aqui, Scotus tem contudo a intenção de deixar explícito 
(a) Scotus acentua que a vontade é livre diante de todo bem, na sua decisão, isto é, não há nenhum bem que possa forçar, de alguma forma, o seu querer (velle). ${ }^{56}$ Correspondentemente a isso, não há também mal algum que seria tão ruim ao ponto de direcionar forçosamente um ato de rejeição da vontade (nolle) em relação a ele. ${ }^{57}$

(b) Ao lado do querer e do rejeitar ativos, há, ainda, uma terceira forma de tomada de posição volitiva, a qual significa uma forma de abstenção de juízo: o não-querer (non velle). Enquanto o nolle, tal como o velle, forma um ato positivo da realização da vontade, ${ }^{58}$ o não-querer se iguala a uma suspensão da atividade da vontade. ${ }^{59}$ Essa atitude do non velle é, pois, possível diante de todo bem representado e representável em ato ${ }^{60}$ Se devesse haver também objetos, daí bens, aos quais nenhuma ação de recusa poderia se dirigir, tendo como base a sua bondade universal ou a sua liberdade de carência de toda sorte, não se seguiria que eles seriam queridos necessariamente, daí que nós não poderíamos não-querê-los: um não-querer, de acordo com Scotus, reside sempre no domínio do possível.

(c) A partir disso, tem-se como resultado um distanciamento acentuado face às premissas de teoria da ação típicas de um paradigma aristotélico-tomasiano: também a felicidade, daí o bonum simpliciter na forma de Deus, podem não ser queridos ${ }^{61}$. Mesmo o bem pura e simplesmente, com isso, não é um objeto necessário da vontade, como Scotus também explica em oposição a Henrique de Gand, ${ }^{62}$ mas o querer da felicidade tem em si um caráter contingente. ${ }^{63} \mathrm{Na}$ medida em que a vontade humana é um desejo natural por perfeição (voluntas naturalis), ela é, sem dúvida, naturalmente direcionada à felicidade, o que, entre outras coi-

que nenhum juízo de razão equívoco sub ratione boni tem de preceder o querer mau. A vontade pode também se dirigir diretamente ao malum, mas não sub ratione mali.

${ }^{56}$ Cf. Ord. I d. 1, n. 147, ed. Vat. II p. 98: "necessitas est in intellectu propter evidentiam obiecti necessario causantis assensum in intellectu: non autem bonitas aliqua obiecti causat necessario assensum voluntatis, sed voluntas libere assentit cuilibet bono, et ita libere assentit maiori bono sicut minori". Cf. Ord. II d. 7, q. un., n. 90, ed. Vat. VIII p. 117: "Voluntas autem non cogitur ex bonitate obiecti; ideo potest esse ita aversa quod quantumcumque bonum sibi ostensum non movet ipsam ad amandum ipsum, saltem ordinate".

${ }^{57}$ Rep. II d. 39, q. 1-2, n. 4, ed. Viv. XXIII p. 204b: "igitur non est aliquod ita malum, quod possit sibi ostendi, et sub ratione quantumcumque noti, a quo necessario dissentiat. Non enim habet necessario nolle respectu mali noti, nec velle respectu boni qualitercumque cogniti in via".

${ }^{58}$ Cf. Ord. II d. 6, q. 2, W p. 462: "est enim nolle actus positivus voluntatis, quo fugit disconveniens sive quo resilit ab obiecto disconveniente; velle autem est actus quo acceptat obiectum aliquod conveniens”. Cf. também Rep. II d. 6, q. 2, n. 4, ed. Viv. XXII p. 619a: Velle e nolle são os „actus positivi voluntatis", em que o nolle depende, em última análise, logicamente e em termos de conteúdo do velle: "nolle non potest esse primus actus voluntatis; tum quia nolle non est nisi propter velle".

59 Cf. HOERES, Der Wille als reine Vollkommenheit [nota 8], p. 118.

${ }^{60}$ Cf. Rep. d. 39, q. 2, n. 5, ed. Viv. XIII p. 205a: "tamen non velle negative potest voluntas habere respectu cuiuscumque obiecti".

${ }^{61}$ Cf., para o que segue, sobretudo Ord. IV suppl. d. 49, q. 9-10, W p. 182-196.

62 Cf., quanto a esta crítica de Scotus a Henrique de Gand, J. SPRUYT, Duns Scotus's criticism of Henry of Ghent's notion of free will, in: E. P. BOS (ed.), John Duns Scotus. Renewal of philosophy, Amsterdam/Atlanta, 1998, p. 139-154 (em especial, p. 148-150).

63 Cf. Ord. IV suppl. d. 49, q. 9-10, W p. 188: "Dico ergo quod contingenter vult finem et beatitudinem tam in universali quam in particulari". 
sas, significa que, aqui, uma recusa ativa (nolle) lhe é tão pouco possível quanto o querer a infelicidade. ${ }^{64}$ Mas, na medida em que a vontade é livre (voluntas libera), ela também pode se abster, aqui, de querer em sentido positivo ou em sentido negativo, isto é, também aqui está fora de questão toda e qualquer necessitação da vontade. ${ }^{65}$ Scotus acentua igualmente que nem tudo o que é feito é feito por causa da própria felicidade. ${ }^{66}$ A esse abandono de um axioma fundamental da ética desiderativa aristotélico-tomasiana ${ }^{67}$ se vinculam conseqüências de amplo alcance, pois, por meio disso, é implodida a estrutura teleológica desse modelo: os objetos de decisão volitiva não têm em si o caráter de um fim (finis), caráter este que leva, então, ao ser desejado daqueles. Antes, eles obtêm o seu caráter de fim primeiramente através do ato da vontade. ${ }^{68}$

Sob essas premissas, modificadas em termos de teoria da ação, tanto em comparação com Tomás de Aquino quanto em comparação com Henrique de Gand, pode ser deduzido de que modo é fundamentalmente possível não fazer aquilo que se toma como o correto, daí como o melhor: à vontade está sempre aberta a possibilidade do não-querer. E essa abstenção de juízo não está ligada a qualquer condição sub ratione boni. Na medida em que a omissão de uma ação freqüentemente constitui em si o ato do pecado, também uma fraqueza da vontade refletida, com conteúdo pecaminoso, é possível. A ser esclarecida fica sempre de novo a questão de que modo se pode ter agido ativamente contra o juízo prático, por conseguinte contra a própria consciência, portanto de que modo é possível o direcionamento do próprio querer a um peccatum ex certa malitia.

Uma explicação para a possibilidade do peccatum ex certa malitia é prometida pela visão da angelologia de Scotus, sobretudo com respeito à pergunta como a queda do primeiro anjo foi possível. Dado que ali não se pode tratar, nem de um pecado por paixão (porque os anjos não possuem anima sensitiva), nem de um pecado condicionado por insuficiência intelectual, daí pelo erro, dever-se-ia poder

Cf. ibid., W p. 192

${ }^{65}$ Cf. ibid., W p. 188: "etsi voluntas viatoris ut in pluribus velit beatitudinem in universali apprehensam et particulari, quando intellectus iudicat vel non dubitat in illo particulari esse beatitudinem, tamen non necessario vult beatitudinem nec in universali nec in particulari". Cf. ibid., W p. 194: "Ad rationem opinionis quando accipitur quod illud in quo non est ratio mali nec defectus boni necessario est volitum a voluntate, dico quod falsa est huiusmodi, quia voluntas respectu cuiuscumque actus volendi aut nolendi libera est, et a nullo obiecto necessitatur. [...] Unde potest suspendere se ab omni actu, ostensa beatitudine. Unde quodlibet obiectum potest voluntas non velle nec nolle, et a quolibet actu in particulari potest se suspendere circa hoc vel illud". Cf. também Lect. I d. 1, p. 2, q. 2, n. 118, ed. Vat. XVI p. 100: "licet non potest nolle beatitudinem, potest tamen non velle illud".

${ }^{66}$ Cf. Ord. IV suppl. d. 49, q. 9-10, W p. 194: "dico quod non oportet quod voluntas appetat quidquid appetit propter finem ultimum ut propter beatitudinem".

67 Cf., exemplarmente, THOMAS VON AQUIN, STh. I q. 60, a. 2, resp.: "Unde voluntas naturaliter tendit in suum finem ultimum: omnis enim homo naturaliter vult beatitudinem. Et ex hac naturali voluntate causantur omnes aliae voluntates: cum quidquid homo vult, velit propter finem".

68 Cf., nesse sentido, também HOERES, Der Wille als reine Vollkommenheit [nota 8], p. 121, bem como H. MÖHLE, Ethik als scientia practica nach Johannes Duns Scotus. Eine philosophische Grundlegung, Münster, 1995, p. 444: "Der dem Willen vom Intellekt dargebotene Gegenstand ist in einem strikten Sinne obiectum des Willens und nicht finis". 
encontrar, aqui, uma chave para o entendimento da fraqueza da vontade refletida. Ademais, Scotus trata da doutrina dos anjos como uma espécie de teste de consistência para o tom afinado dos conhecimentos filosóficos, ${ }^{69}$ de modo que percepções sobre o querer e o agir humanos têm, aqui, um solo de ressonância.

Na busca por um motivo para a queda de Lúcifer, [permitida] por parte de Deus, Scotus se depara, primeiramente, com o motivo de um amor próprio desmedido. O querer dos anjos pode, assim como o querer humano, ser determinado por duas orientações, daí por duas motivações: no caso do velle amicitiae, a vontade se orienta ao objeto por causa do próprio [objeto] querido; no velle concupiscentiae, por sua vez, o próprio sujeito do querer está em primeiro plano, isto é, o amor próprio é a força motora. Essas duas formas de querer estão ligadas com duas afecções da vontade que se acham na base delas, as quais Anselmo de Cantuária já havia denominado: a affectio commodi e a affectio iusti(tiae). ${ }^{70} \mathrm{Na}$ medida em que a vontade segue a affectio commodi, ela se orienta pela auto-realização natural do sujeito do querer, o que, em última instância, não é outra coisa que o desejo natural de felicidade; ao perseguir a affectio iustitiae, ao contrário, a vontade é capaz de um padrão moral mais elevado, que se deve, em última análise, à vontade de Deus. ${ }^{71}$ Scotus não vê, por sua vez, o desejo de felicidade na estrutura da affectio commodi como algo per se imoral ou falso; no entanto, é inerente a ele a tendência de desmedida. Exatamente por causa disso, carece-se de affectio iustitiae como de um contrapeso, por meio do qual o amor próprio da affectio commodi

${ }_{69}$ Cf. Additiones magnae, d. 25, q. 1, ed. C. Bali , p. 271: "Unde etsi illud quod nos tenemus de angelis, non possit probari per philosophiam, tamen illud quod non potest stare cum veritate, quam tenemus de angelis, est simpliciter falsum".

70 Cf. Rep. II d. 6, q. 2, n. 22, ed. Viv. XXII p. 619a: "Velle vero duplex est: velle amicitiae et concupiscentiae, et prius est velle amicitiae, quia illud cui vult, est finis respectu istius, quod sibi concupiscit. Primo igitur est velle amicitiae, secundo concupiscentiae, et tertio nolle oppositorum. Similis est ordo in actibus deordinatis voluntatis, nam actus deordinatus non sequitur regulam iustitiae; igitur affectionem commodi ...". Cf. Ord. IV d. 49, q. 5, ed. Viv. XXI p. 172s.: "Velle etiam est duplex in genere: aut propter volitum sive propter bonum voliti aut propter volentem sive propter bonum volentis [...]. Primum velle dicitur esse amoris amicitiae, secundum amoris concupiscentiae [...] actus amicitiae inest voluntati secundum quod habet affectionem iustitiae [...]. Actus autem concupiscentiae inest voluntati secundum quod habet affectionem commodi".

${ }^{71}$ Cf. Rep. II d. 6, q. 2, n.10, ed. Viv. XXII p. 622a: "Appetitus liber [...] est rectus [...] ex hoc, quod vult illud quod Deus vult eum velle. Unde illae duae affectiones commodi et iusti regulantur per regulam superiorem, quae est voluntas divina, et neutrum illorum est regula alterius, et quia affectio commodi ex se forte est immoderata, alia tenetur istam moderari, quia tenetur subesse regulae superiori". Cf. Ord. II d. 6, q. 2, W p. 472. 474: "tenetur enim sequi voluntatem superiorem, ex quo in moderando illam inclinationem naturalem in potestate eius est moderari vel non moderari, quia in potestate eius est non summe agere id quod potest". A interpretação destas passagens, na pesquisa recente, é controversa. Enquanto J. BOLER, Transcending the natural: Duns Scotus on the two affections of the will, in: American Catholic Philosophical Quarterly 57 (1993), p. 109-126, se pronuncia contra uma interpretação em termos de "divine command ethics", Thomas WILLIAMS, How Scotus separates morality from happiness, in: American Catholic Philosophical Quarterly 59 (1995), p. 425-445, constata, contra J. Boler: "the higher will in question is indeed God's will" (ibid., p. 437). 
pode ser mantido e moderado numa estrutura adequada. ${ }^{72} \mathrm{O}$ fato de a vontade dispor da affectio iustitiae chega a ser até mesmo a raiz última da sua liberdade. Em conexão com um experimento de pensamento de Anselmo de Cantuária, Scotus pensa, a modo de hipótese, num anjo que possui apenas a affectio commodi, e não possui, contudo, a affectio iustitiae. Chega à seguinte conclusão: em tal anjo, não se poderia falar, nem de liberdade, nem de pecado, na medida em que o seu agir seria determinado meramente pela sua natureza. ${ }^{73}$ Por isso mesmo, a affectio iustitiae é também a última differentia specifica do querer livre, ${ }^{74}$ e Scotus fala dela, em última instância, como de uma "liberdade inata" da vontade. ${ }^{75}$

$\mathrm{Na}$ aplicação desse instrumentário conceitual ao casus diaboli, Scotus chega, então, à conclusão de que o pecado de Lúcifer consistiu primeiramente num amor desordenado a si mesmo (inordinatus amor amicitiae respectu sui ipsius) - dado que o anjo amou a si mesmo numa medida em que poderia amar apenas a Deus -, amor este que, então, levou a um desejo desmedido pela própria felicidade, no sentido do velle amoris concupiscentiae. ${ }^{76}$ Este último caso se deve claramente à affectio commodi. ${ }^{77}$ Scotus acentua, contudo, ser preciso imaginar essa queda do primeiro anjo, não em termos de um querer atual, mas sim na forma de um desejo latente (velleitas): enquanto a vontade de um anjo, em termos de um velle efficax, em termos, portanto, de uma decisão, que inclui o cálculo dos meios adequados para a realização do conteúdo da vontade, não pode entrar em contradição para com Deus, o mesmo é, no âmbito de um mero velle complacentiae, absolutamente possível. Aqui, um conteúdo da vontade possível pode ser afirmado em si, sem que as suas conseqüências sejam queridas e sem que se suceda uma deliberação concreta sobre a sua transposição. ${ }^{78}$ Mas, isso em nada modifica o fato de que se

${ }^{72}$ Cf. Ord. II d. 6, q. 2, W p. 468: "Illa igitur affectio iustitiae, quae est prima moderatrix affectionis commodi et quantum ad hoc quod non oportet voluntatem actu appetere illud ad quod inclinat affectio commodi et quantum ad hoc quod non oportet eam summe appetere".

73 Cf. Rep. II d. 6, q. 2, n. 9, ed. Viv. XXII p. 621b; Rep. II d. 25, q. un., n. 20, ed. Viv. XXIII p. 128b; Lect. II d. 25, q. un., n. 33, ed. Vat. XIX p. 238s. Sobre Anselmo de Cantuária, cf. De casu Diaboli c. 12, ed. F. S. Schmitt (Edinburgh 1938, ND Stuttgart 1968), vol. I, p. 251-255.

${ }^{74}$ Rep. II d. 6, q. 2, n. 9, ed. Viv. XXII p. 621b: "ideo affectio iusti est ultima differentia specifica appetitus liberi".

75 Cf. Ord. II d. 6, q. 2, W p. 468: "affectio iustitiae est libertas innata voluntati". Cf. também Ord. III suppl. d. 26, W p. 178, onde a affectio iustitiae é descrita como "ingenita libertas secundum quam potest velle aliquod bonum non ordinatum ad se", em contraste com a affectio commodi: "Secundum autem affectionem commodi nihil potest velle nisi in ordine ad se, et hanc haberet si praecise esset appetitus intellectivus sine libertate sequens cognitionem intellectivam, sicut appetitus sensitivus sequitur cognitionem sensitivam". Sobre o significado fundamental desse contexto para a ética scotista, cf. A. B. WOLTER, Native freedom of the will as a key to the ethics of Scotus, in: Deus et Homo ad mentem I. Duns Scoti. Acta Tertii Congressus Scotistici Internationalis Vindebonae, 28 sept. - 2 oct. 1970, Roma 1972, p. 359-370, bem como L. SUKJAE, Scotus on the will: the rational power and the dual affections, in: Vivarium 36 (1998), p. 40-54.

${ }^{76}$ Cf. Rep. II d. 6, q. 2, ed. Viv. XXII p. 618b-621a; Ord. II d. 6, q. 2, W p. 464

77 Ord. II d. 6, q. 2, W p. 464: "primum concupiscere inordinatum non processit ex affectione iustitiae, sicut nec aliquod peccatum processit; ergo ex affectione commodi".

${ }^{78}$ Cf. Rep. II d. 6, q. 1, n. 5, ed. Viv. XXII p. 615b: "distinguendum de actu volendi; est enim duplex, simplex, et cum conditione. Simplex, qui est efficax, quando quis credit volitum sibi esse possibile, et eligit media ad consequendum illud, et importat executionem. Velle cum conditione est velleitas 
trata de um pecado, o qual Scotus, também com clareza, classifica como peccatum ex electione, em destituição do peccatum ex passione, daí do peccatum ex ignorantia. $^{79}$ a vontade do anjo se choca, no âmbito do desejo latente, contra aquilo que ele conheceu como o único verdadeiro bem, a saber, Deus, daí o amor de Deus, sem que, em compensação, causalmente se pudesse nomear uma outra coisa que não ele mesmo.

O que se pode ganhar, a partir dessas especulações angelológicas, para o entendimento do pecado humano e da fraqueza da vontade? Primeiro, elas evidenciam de que modo Scotus chega, em absoluto, à sua delimitação, acima descrita, do desejo de felicidade como o determinante em termos de teoria da ação: com a introdução da affectio iustitiae é nomeada uma motivação de ação que pode limitar o desejo de felicidade que repousa na affectio commodi, por conseguinte pode transcender a ações que não se devem ao desejo da realização própria. ${ }^{80}$ Em última análise, está preparado aqui o chão para uma separação entre natureza e moral, como já se coloca na distinção scotista entre natura e voluntas: a responsabilidade e a bondade morais começam antes de tudo ali onde a vontade opera, não mais meramente a modo de natureza, mas sim em autodeterminação livre ${ }^{81}$ Como potência natural, a vontade está fixada na felicidade; como potência livre, ao contrário, ela também pode não querer a felicidade, daí até mesmo produzir um querer contrário a ela ${ }^{82}$. A possibilidade de não-querer a beatitudo está fundamentada, assim, no transcender do natural e da affectio commodi possibilitado pela affectio iustitiae. Isso também se faz notável na conceitualização da vontade, em que Scotus a concebe - em oposição à tradição aristotélico-tomasiana e também a Henrique de Gand - não mais essencialmente como desejo racional (appetitus rationalis). Isso se liga primariamente ao fato de ele identificar a affectio commodi com o appetitus intellectualis, ${ }^{83}$ tal que, com isso, o desejo racional caracteriza, de

intensa aliquando ad finem habendum, non tamen est velle efficax, quia non importat media ad consequendum finem". Para a diferenciação, nos mesmos termos, entre velle complacentiae e velle efficax, cf. Ord. I d. 8, p. 2, q. un., ed. Vat. IV, p. 309 (adnotatio); Ord. III d. 33, W p. 338.

${ }^{79}$ Cf. Rep. II d. 6, q. 1, n. 6, ed. Viv. XXII p. 616a, onde Scotus aponta corretamente para o fato de que o conceito de electio, normalmente ligado necessariamente à escolha dos meios, para efeito de classificação do pecado angelical como peccatum ex electione, tem de ser um tanto expandido.

${ }^{80}$ Cf. Ord. II d. 6, q. 2, W p. 470: "Secundum hoc ergo patet quod voluntas libera non tenetur omni modo velle beatitudinem (quae voluntas si esset tantum appetitus intellectivus, sine libertate, vellet eam), sed tenetur in eliciendo actum moderari appetitum unde appetitus intellectivus, quod est moderari affectionem commodi, ne scilicet immoderate velit".

81 Para a diferenciação entre natura e voluntas, cf. Scotus, QQ in Metaph. IX q.15, n. 20-34, ed. G. Etzkorn et al. (St. Bonaventure/N.Y. 1997) p. 680-684, bem como T. HOFFMANN, The distinction between nature and will in Duns Scotus, in: Archives d'Histoire Doctrinale et Littéraire du Moyen Age 66 (1999), p. 189-224. Cf. Ord. II d. 42, q. 1-4, n. 1, ed. Viv. XIII p. 448b: "Omnis causa activa in universo praeter voluntatem est naturaliter activa; ergo nulla praeter voluntatem est vituperabilis propter suam actionem".

${ }^{82}$ Cf. Lect. II d. 39, q. 1-2, n. 29, ed. Vat. XIX p. 385: "voluntas tendit naturaliter in beatitudinem sicut lapis naturaliter tendit deorsum. [...] Sed tamen voluntas libera potest velle secundum istam naturalem inclinationem, vel contra eam: et si velit secundum eam concorditer, tunc dicitur habere velle naturale; et si opposito modo, tunc dicitur habere velle contra inclinationem naturae".

${ }^{83}$ Cf. Ord. II d. 6, q. 2, W p. 468; Ord. II d. 39, q. 2, W p. 202; Ord. III suppl. d. 26, W p. 178. Cf. também Thomas WILLIAMS, How Scotus separates [nota 71], p. 427s. 
fato, o aspecto do querer natural. Exatamente nisso, porém, não consegue alcançar a liberdade da vontade que repousa na affectio iustitiae. A vontade é de fato uma - se não, em absoluto, a única - potentia rationalis, uma vez que ela, em oposição às outras potências ativas, não está fixada naturalmente num determinado modo de causação, mas sim dispõe de indiferença de ato, de indiferença de objeto e de indiferença de operação. ${ }^{84}$ De qualquer modo, Scotus subtrai da vontade, na medida em que ela é livre, de modo radical o aspecto do desejo. Através disso, o conceito de vontade, em Scotus, recebe um cunho próprio também face aos seus precursores "voluntaristas", como Henrique de Gand.

Assim, Scotus deixa claro que a vontade não está orientada necessariamente àquilo que reside no próprio desejo de felicidade, muito menos está ela orientada necessariamente à justiça, daí à vontade de Deus: a vontade pode não querer tanto o commodum quanto o iustum. ${ }^{85}$ Dito de modo positivo: sob preservação da sua unidade como potência, ${ }^{86}$ a vontade dispõe de dois possíveis motivos de fundamentação, os quais, contudo, não têm de estar per se numa oposição: afinal, a sua perspectiva de fim é, em consideração precisa, idêntica, na medida em que o desejo de felicidade tem como fim a Deus como finis beatificans, e a affectio iustitiae está orientada ao bonum honestum, o qual, em última análise, é idêntico a Deus. ${ }^{87}$ Não obstante isso, o desejo segundo auto-realização natural e as exigências da moral, a affectio commodi e a affectio iustitiae, podem chegar a entrar em contradição, contradição da qual o agente pode também, como tal, estar consciente. E, com isso, oferece-se ao mesmo tempo uma explicação ao modo como é possível uma ação contra aquilo que é corretamente conhecido, em sentido moral: no caso paradigmático, a vontade se decide a favor do commodum contra as exigências da justiça. Para tanto, nem precisa ela de um princípio externo, na forma das paixões, na medida em que a affectio commodi reside nela como um momento natural, nem é forçosamente necessário, sob a fundamentação das premissas respectivas à teoria da ação, acima desenvolvidas, que o agente aja a partir de um juízo de razão errôneo: a violação da sua ação face às exigências da ordem moral pode lhe estar claramente diante dos olhos e meramente retrocede, em sentido preferencial, para trás do desejo de felicidade. Com isso, porém, não é estabelecida outra coisa que a possibilidade do peccatum ex certa malitia, daí da fraqueza da vontade refletida.

84 Para estes aspectos do fenômeno fundamental da liberdade da vontade, cf. J. SÖDER, Kontingenz und Wissen. Die Lehre von den futura contingentia bei Johannes Duns Scotus, Münster, 1998, p. 88-91. Sobre a vontade como potentia rationalis, cf. também A. B. WOLTER, The philosophical theology of John Duns Scotus, ed. M. McCord Adams, Ithaca/London, 1990, p. 163-180.

85 Cf. Lect. II d. 39, q. 1-2, n. 28, ed. Vat. XIX p. 385: "sed actus quilibet elicitus a voluntate est nonnecessarius circa commodum sicut circa iustitiam". Cf. Ord. II d. 39, W p. 202: "Dico ergo quod ista propositio Anselmi , Commoda non velle nequit', debet intelligi non loquendo de tota potentia, quae modo libere[o ?] potest non velle non tantum commoda sed etiam iusta, quia libere potest haec et illa non velle".

${ }^{86}$ Cf. Ord. III d. 17, W p. 182: "Unde eadem potentia dicitur naturalis voluntas cum respectu tali necessario consequente ipsam ad perfectionem, et dicitur libera secundum relationem propriam et intrinsecam, quae est voluntas specifice".

87 Cf. B. KENT, Virtues of the will [nota 21], p. 197s. 


\section{Conclusão}

Voltemos à pergunta que havia sido o ponto de partida, isto é, o problema da fraqueza da vontade não desempenha papel algum em Scotus? Sim e não. A pergunta tem certamente de ser respondida de modo afirmativo, na medida em que esse tipo de ação é ligado, na sua forma de leitura tradicional, aristotélicotomasiana, à influência das paixões (passiones) como o fator que evoca esse tipo de ação, através de uma influência de atividade cognitiva. O modelo de Scotus, como foi visto, deixa de fato espaço para tal peccare ex infirmitate/passione, mas este mesmo não representa, manifestamente, um real problema para ele. Por outro lado, a pergunta tem de ser respondida de modo negativo, quando se entende por fraqueza da vontade primariamente uma ação contra o melhor juízo, na qual se age conscientemente contra um juízo precedente. Este fenômeno é, também para Scotus, como na sua discussão com um determinismo intelectual a modo de Godofredo de Fontaines, extremamente relevante, uma vez que se trata, aqui, da pergunta central, para Scotus, pela liberdade da vontade. A problemática que o move, neste caso, é a do peccare ex certa malitia, daí da fraqueza da vontade refletida. Para que tal agir seja em absoluto possível, precisa-se de uma radicalização da liberdade de escolha da vontade, a qual Scotus realiza através das modificações anunciadas em termos de teoria da ação (renúncia do princípio sub ratione boni e da necessária orientação para a felicidade), da sua doutrina das afecções e da nova concepção do conceito de vontade livre (negação do conceito de appetitus rationalis). ${ }^{88}$

A fraqueza da vontade refletida é, com isso, um problema absolutamente genuíno e carente de explicação para Scotus, mas a sua solução, em compensação, é, ao final, apta a levar discussões posteriores ao emudecimento. Quando se busca para o próprio ato da vontade ainda uma explanação posterior, essa busca de pistas leva ao vazio: para o fato de que a vontade se determina a este e não àquele outro, não há nenhuma outra causa que ela mesma: "nulla est causa nisi quia voluntas est voluntas" ${ }^{89} \mathrm{Com}$ isso, fica também claro no que a liberdade da vontade se fundamenta: não primariamente na sua indiferença, portanto na opção de poder realizar ou querer o contrário, mas, em primeira linha, no poder de uma autodeterminação, radicalmente enraizada na atualidade da vontade, e em nada

${ }^{88}$ Que se deve partir - contrariamente a uma opinião difundida na pesquisa, por muito tempo, em associação à opinião de Bali -, dentro das obras de Scotus, antes de uma radicalização do que de uma moderação do conceito de vontade, isso foi demonstrado de modo deveras convincente por St. D. DUMONT, Did Scotus change his mind on the will?, in: J. A. AERTSEN; K. EMERY; A. SPEER (Hrsg.), Nach der Verurteilung von 1277. Philosophie und Theologie an der Universität von Paris im letzten Viertel des 13. Jahrhunderts. Studien und Texte (Miscellanea Mediaevalia, 28), Berlin/New York, 2001, p. 719-794.

89 Ord. I d. 8, p. 2, q. un. n. 299, ed. Vat. IV p. 325. Cf. também QQ in Metaph. IX q. 15, n. 29, p. 682: "stabitur alicuibi. Ubi? Quare voluntas illud volet? Nulla est alia causa nisi quia est voluntas". Lect. I d. 8, p. 2, q. un., n. 279, ed. Vat. XVII p. 105: "unde quaerere quid determinat voluntatem, est quaerere quare voluntas est voluntas". 
mais. ${ }^{90} \mathrm{Na}$ indeterminação da vontade, não se trata, de maneira alguma, de uma não-determinação, que traz em si alguma forma de potencialidade, daí que falta em atualidade (indeterminatio insufficientiae), assim como a matéria, com respeito à forma, é não-determinada. Tal forma de indeterminação carece sempre de um momento que ingressa a partir de fora, o qual tem, como conseqüência, a determinação para um de dois contrários. A vontade, diferentemente, dispõe de uma atualidade ilimitada e, com isso, como expressa Scotus, de uma indeterminação de ilimitação (indeterminatio illimitationis), daí de uma indeterminatio superabundantis sufficientiae. Essa não-determinação se contrapõe a toda forma de privação e de passividade, e a afirmação da vontade ocorre ativamente a partir de si mesma. ${ }^{91}$

Conseqüentemente, a pergunta por que a vontade fraca refletida age contra o seu próprio juízo sobre o bem, daí sobre o correto, pode apenas ser respondida com uma remissão à liberdade absolutamente contingente da vontade. Mais, segundo Scotus, não é possível dizer. E deve-se anotar ao lado disso: também a moderna teoria da ação se depara com um cerne aparentemente irredutível do fenômeno, o qual se distancia de uma possibilidade de explicação puramente racional. ${ }^{92}$ Mais, porém, de acordo com Scotus, também não é necessário: quem concebeu a essência da vontade na sua liberdade radical, entende também como o peccatum ex certa malitia, daí a fraqueza da vontade refletida (e, com isso, a fraqueza da vontade na sua variante mais forte) é possível. E quem aceita esse conceito de vontade com todas as suas implicações, para este o agir contra o melhor juízo também não é mais um absoluto enigma, mas sim uma expressão explícita da liberdade da vontade humana. Nessa maneira de ver, é legítimo dizer que, na ética scotista, o problema da fraqueza de vontade desaparece, em última instância, na medida em que ele perde a sua agudeza filosófica exatamente na metafísica da vontade.

Traduzido do alemão por Roberto Hofmeister Pich

90 Cf. Lect. I d. 8, p. 2, q. un., n. 278, ed. Vat. XVII p. 105: "indeterminatio potentiae activae naturalis tantum est ad unam partem contradictionis, sed indeterminatio agentis primi voluntarie est respectu utriusque partis contradictionis cum potestate determinandi se". Cf. também Additiones Magnae, p. 275: "Sed voluntas non sic determinatur naturaliter, sed est indeterminata indeterminatione alterius rationis ab indeterminatione cuiuslibet alterius potentie; quia quaelibet alia est naturalis et limitata, hec sola est indifferens ex libertate, ideo determinat se libere. Unde hec est perfecta causalitas, que non habet similem, quia hec sola libera est, et ideo non potest simile in natura inveniri". Cf. M. E. INGHAM, Ethics and freedom. An historical-critical investigation of Scotist ethical thought, Lanham, 1989, p. 77: "the will's freedom which Scotus presents is not mere indifference but rather a creative freedom capable of self-determination".

${ }^{91}$ Para a delimitação da indeterminação específica da vontade diante de outras formas de nãodeterminação, cf. QQ. in Metaph. IX q. 15, n. 31-34, p. 683s.; Additiones magnae, p. 275s.; Lect. I d. 8, p. 2, q. un., n. 278, ed. Vat. XVII p. 105; Lect. II d. 25, q. un., n. 92-93, ed. Vat. XIX p. 260s.

92 Cf. D. DAVIDSON, How is weakness of the will possible? [nota 2], p. 42: "But in the case of incontinence, the attempt to read reason into behaviour is necessarily subject to a degree of frustration. What is special in incontinence is that the author cannot understand himself: he recognizes, in his own intentional behaviour, something essentially absurd". 